\title{
Effects of organic and inorganic manures on maize and their residual impact on soil physico-chemical properties
}

\author{
Faisal Mahmood ${ }^{1}$, Imran Khan ${ }^{2,3 *}$, Umair Ashraf4,5, Tanvir Shahzad ${ }^{1}$, Sabir Hussain ${ }^{1}$, \\ Muhammad Shahid ${ }^{6}$, Muhammad Abid², Sami Ullah²
}

${ }^{1}$ Department of Environmental Sciences \& Engineering, Government College University Faisalabad 38000, Pakistan.

${ }^{2}$ Department of Agronomy, University of Agriculture, Faisalabad, 38040, Pakistan.

Corresponding author: drimran@uaf.edu.pk

${ }^{3}$ Department of Plant Sciences, University of California, One Shields Avenue, Davis, CA 95616, USA.

${ }^{4}$ Department of Crop science and Technology, College of Agriculture, South China Agricultural University, Guangzhou, 510642 China;

${ }^{5}$ Scientific Observing and Experimental Station of Crop Cultivation in South China, Ministry of Agriculture. P. R. China, Guangzhou, 510642, Guangdong, China;

${ }^{6}$ Department of Bioinformatics \& Biotechnology, Government College University Faisalabad 38000, Pakistan.

\begin{abstract}
Organic and inorganic nutrients are important for crop productivity and soil health. Present study investigated the effects of organic and inorganic manures on maize and their residual impacts on soil physico-chemical characteristics. Sheep manure (SM), poultry manure (PM) and farmyard manure (FYM) were applied as organic nutrient source while urea, diammonium phosphate (DAP) and sulphate of potash (SOP) were used at different concentrations as inorganic nutrients source viz., $\mathrm{T}_{1}$ : Unfertilized control; $\mathrm{T}_{2}: \mathrm{NPK}$ at 250-150-125 $\mathrm{kg} \mathrm{ha}^{-1} ; \mathrm{T}_{3}$ : $\mathrm{SM}$ at $15 \mathrm{t} \mathrm{ha}^{-1} ; \mathrm{T}_{4}: \mathrm{FYM}$ at $16 \mathrm{t} \mathrm{ha}^{-1} ; \mathrm{T}_{5}: \mathrm{PM}$ at $13 \mathrm{t} \mathrm{ha}^{-1} ; \mathrm{T}_{6}: \mathrm{NPK}$ at $150-85-50+8 \mathrm{tha}^{-1} \mathrm{SM} ; \mathrm{T}_{7}: \mathrm{NPK}$ at $150-$ $85-50+8.5 \mathrm{tha}^{-1} \mathrm{FYM}$ and $\mathrm{T}_{8}$ : NPK at 150-85-50 $+7 \mathrm{tha}^{-1} \mathrm{PM}$. Results showed that growth and yield of maize were substantially improved by fertilizer application alongside organic manures whereas soil total organic $\mathrm{C}$ and total N, P, K contents increased when inorganic fertilizers were applied alone or in combined with organic manures. However, soil $\mathrm{pH}$ and soil bulk density decreased due to application of organic fertilizer and showed a negative correlation with grain yield. Further, a significant and positive correlation $\left(\mathrm{R}^{2}=0.52,0.91\right.$ and 0.55$)$ was observed among maize grain yield and available N, P and K contents, respectively in the soil. Conclusively, integration of inorganic fertilizers with organic manures can be used with optimum rates to improve crop productivity on sustainable basis. This study will be helpful in crafting sustainable nutrient management programs in future to enhance crop productivity with high efficiency and minimum nutrient loss.
\end{abstract}

Keywords: Growth, manures, maize, soil characteristics, yield 


\section{Introduction}

Maize (Zea mays L.) is the most important cereal worldwide (Ashraf et al., 2016a). Only the USA, China and Brazil contribute $63 \%$ to the global maize production whilst Mexico, Argentina, India, Ukraine, Indonesia, France, Canada and South Africa are also major maize producing countries (FAO, 2012). Many factors like soil fertility, imbalanced nutrition, disturbed soil properties, cultivars being grown weed infestation etc. limit its yield worldwide. Different management practices are adopted to increase and optimize the maize yields. For example, use of organic manures alongside inorganic fertilizers often lead to increased soil organic matter (SOM), soil structure, water holding capacity and improved nutrient cycling and helps to maintain soil nutrient status, cation exchange capacity (CEC) and soil's biological activity (Saha et al., 2008). Although chemical fertilizers are important input to get higher crop productivity, but over reliance on chemical fertilizers is associated with decline in some soil properties and crop yields over time (Hepperly et al., 2009). Therefore, an integrated use of inorganic fertilizers with organic manures is a sustainable approach for efficient nutrient usage which enhances efficiency of the chemical fertilizers while reducing nutrient losses (Schoebitz and Vidal, 2016). Synergistic effects of organic manures with inorganic fertilizers accumulate more total nitrogen in soils (Huang et al., 2007), but sole application of farm yard manure (FYM) resulted in increased yield of maize (Anatoliy and Thelen, 2007), higher SOM content (44\%), improved soil porosity (25\%) and 16 times more water holding capacity (Gangwar et al., 2006). A long term residual effect on soil organic C and soil $\mathrm{P}$ (about 7 to 8 years) were reported by $\mathrm{Ki}$ handa et al., (2006) when organic manure was applied in a semi-arid dryland agriculture. Organic manures also affect the soil biological activity (Arau Jo and
Monteiro, 2006), while enhanced phosphorous (P) availability is also well reported with the application of organic manures in the soil (Toor and Bahl, 1997). Ancient farmers used to rely on organic manures for crop production that proved good for soil health but was slow in response on crop yields. Now, swift economic development has led the farmers to use mineral fertilizers as they are more economical, affordable, easy to use and quick in response. However, their intensive application is leading to land degradation, deteriorated soil health and leaching of nutrients into the underground water thereby posing environmental risks to human and animal health. So, there is a need to draw a mid-way between organic and inorganic extremities that may sustain crop yields without deteriorating soil fertility and/or productivity. Keeping all these aspects in consideration, the present study was therefore conducted to evaluate the effects of organic and inorganic manures on growth and yield of maize and to assess their residual impacts on soil properties.

\section{Materials and Methods}

\subsection{Site description and treatments}

The experiment was conducted at Agronomic Research Farm, University of Agriculture Faisalabad, Pakistan $\left(31.25^{\circ} \mathrm{N}\right.$ latitude, $73.09^{\circ} \mathrm{E}$ longitude, altitude $184 \mathrm{~m})$. The soil of experimental site belongs to Lyallpur soil series (Aridisol-fine-silty, mixed, hyperthermic Ustalfic, Haplargid in USDA classification and Haplic Yermosols in FAO classification). This is a semi-arid region with annual rainfall of 200-250 mm and the maximum and minimum temperature 4.4 ${ }^{\circ} \mathrm{C}$ (in January) and $48{ }^{\circ} \mathrm{C}$ (in June) (Ashraf et al., 2016b). The experiment was laid out in randomized 
complete block design (RCBD) in triplicate. The net plot size was $8 \mathrm{~m} \times 4.5 \mathrm{~m}$ with six rows in each plot having $75 \mathrm{~cm}$ and $20 \mathrm{~cm}$ distance between and within rows, respectively with 65000 plants ha ${ }^{-1}$ plant population. Urea $(46 \% \mathrm{~N})$, di-ammonium phosphate (DAP) $(18 \% \mathrm{~N}, 46 \% \mathrm{P})$ and sulfate of potash SOP $(50 \% \mathrm{~K})$ were used as inorganic sources while farmyard manure (FYM), poultry manure (PM) and sheep manure (SM) were used as organic nutrient source. Random samples of FYM, PM and sheep manures were collected from the bulks separately, air-dried, ground, sieved and then analyzed for dry matter, total organic $\mathrm{C}$, total $\mathrm{N}$, total $\mathrm{P}$, total $\mathrm{K}$ and C:N ratio (Chapman and Pratt 1961). Composition of organic manures used in the experiment is given in the Table 1.

Following treatments were used in this experiment:
$\mathrm{T}_{1}$ : Unfertilized control

$\mathrm{T}_{2}$ : NPK at $250-150-125 \mathrm{~kg} \mathrm{ha}^{-1}$

$\mathrm{T}_{3}: \mathrm{SM}$ at $15 \mathrm{tha}^{-1}$

$\mathrm{T}_{4}$ : FYM at $16 \mathrm{tha}^{-1}$

$\mathrm{T}_{5}: \mathrm{PM}$ at $13 \mathrm{tha}^{-1}$

$\mathrm{T}_{6}$ : NPK at $150-85-50+8 \mathrm{tha}^{-1} \mathrm{SM}$

$\mathrm{T}_{7}$ : NPK at 150-85-50+8.5 $\mathrm{tha}^{-1} \mathrm{FYM}$

$\mathrm{T}_{8}$ : NPK at $150-85-50+7 \mathrm{tha}^{-1}$ PM 2.2

\subsection{Soil characteristics determination}

Soil samples $(0-30 \mathrm{~cm})$ were collected from different locations of the experimental site and mixed thoroughly to make a composite sample to determine its physico-chemical characteristics (Table 2). After air drying and grinding, it was passed through 2-mm sieve and following soil properties were determined: (i) soil bulk density, (ii) soil organic carbon, (iii) Soil $\mathrm{pH}$, (iv) total $\mathrm{N}, \mathrm{P}, \mathrm{K}$ contents, and (v) cation exchange capacity, according to methods devised by Sparks (1996).

Table 1. Composition of organic manures used in the experiment

\begin{tabular}{lcccccc}
\hline $\begin{array}{l}\text { Nutrients } \\
\text { Source }\end{array}$ & $\begin{array}{c}\text { Total O.C } \\
(\%)\end{array}$ & C:N & D.M (\%) & $\begin{array}{c}\text { Total N } \\
(\%)\end{array}$ & $\begin{array}{c}\text { Total P } \\
(\%)\end{array}$ & Total K (\%) \\
\hline FYM & 17.5 & 19 & 65.3 & 1.30 & 0.41 & 0.73 \\
PM & 21.2 & 20 & 78.5 & 1.75 & 0.65 & 1.07 \\
SM & 19.6 & 18 & 73.3 & 1.50 & 0.45 & 0.97 \\
\hline
\end{tabular}

O.C. $=$ organic carbon; D.M. $=$ dry matter

\subsection{Growth and yield}

Leaf samples were taken at 15 days interval till harvesting for the determination of leaf area index (LAI) and measured by formula: $\mathrm{LAI}=\mathrm{L} \times \mathrm{W} \times \mathrm{A}$, Where: $\mathrm{L}$ is leaf length, $\mathrm{W}$ is the maximum leaf width and $\mathrm{A}$ is a factor of 0.75 for maize crop described by Dwyer and Stewart (1986). Only the maximum values achieved regarding LAI are presented in the table 3. Furthermore, grain and biological yield were recorded at crop maturity from each plot. Finally harvest index (HI) was calculated as the percentage (\%) of grain yield / total plant dry biomass.

\subsection{Data analysis}

Dataset was statistically analyzed by using statistix 8.1 software (Analytical, Tallahassee, Florida, USA) while the difference amongst treatments were separated by using least significant difference (LSD) test at $p \leq 0.05$. 
Table 2. Physico-chemical characteristics of soil before experiment

\begin{tabular}{ll|lc}
\hline \multicolumn{2}{c|}{ Chemical analysis } & \multicolumn{2}{c}{ Particle size analysis } \\
\hline Soil Characteristics & Values & Soil Characteristics & Values \\
\hline Total organic carbon & $0.75 \%$ & Sand & 54.07 \\
Saturation percentage & $35.8 \%$ & Silt & 20.48 \\
Cation exchange capacity (CEC) & $17.2 \mathrm{cmol} / \mathrm{kg}$ & Clay & 25.45 \\
Bulk Density & $1.49 \mathrm{~g} \mathrm{~cm}^{-3}$ & Textural class & \\
$\mathrm{C}: \mathrm{N}$ & 11.7 & & \\
$\mathrm{pH}$ & 7.6 & & \\
Total nitrogen (N) & $0.07 \%$ & & \\
Total available phosphorous (P) & $16.1 \mathrm{ppm}$ & & \\
Total available potassium (K) & $172 \mathrm{ppm}$ & & \\
\hline
\end{tabular}

Table 3. Effect of organic and inorganic manures on LAI, grain weight, grain and biological yield as well as harvest index

\begin{tabular}{|c|c|c|c|c|c|}
\hline Treatments & Leaf Area Index & $\begin{array}{l}\text { 1000-grain weight } \\
(\mathrm{g})\end{array}$ & $\begin{array}{c}\text { Grain yield } \\
\left(\mathrm{t} \mathrm{ha}^{-1}\right)\end{array}$ & $\begin{array}{l}\text { Biological } \\
\text { yield }\left(\mathrm{t} \mathrm{ha}^{-1}\right)\end{array}$ & Harvest index $(\%)$ \\
\hline $\mathrm{T}_{1}$ & $3.91 \pm 0.07 \mathrm{f}$ & $171.3 \pm 0.83 \mathrm{~g}$ & $4.02 \pm 0.02 \mathrm{~h}$ & $8.53 \pm 0.05 \mathrm{e}$ & $47 \pm 0.01 \mathrm{~d}$ \\
\hline $\mathrm{T}_{2}$ & $\begin{array}{c}5.23 \pm 0.09 \mathrm{c} \\
(33.76)\end{array}$ & $\begin{array}{c}198.5 \pm 0.47 \mathrm{~d} \\
(16.03)\end{array}$ & $\begin{array}{c}7.50 \pm 0.11 \mathrm{~d} \\
(87.91)\end{array}$ & $\begin{array}{c}13.71 \pm 0.02 \mathrm{~d} \\
(61.02)\end{array}$ & $\begin{array}{c}54 \pm 0.02 \mathrm{bc} \\
(16.70)\end{array}$ \\
\hline $\mathrm{T}_{3}$ & $\begin{array}{l}5.01 \pm 0.05 \mathrm{~d} \\
(28.82)\end{array}$ & $\begin{array}{c}187.9 \pm 0.41 \mathrm{e} \\
(9.67)\end{array}$ & $\begin{array}{c}6.84 \pm 0.05 \mathrm{f} \\
(69.54)\end{array}$ & $\begin{array}{c}12.13 \pm 0.01 \mathrm{~d} \\
(42.47)\end{array}$ & $\begin{array}{l}56 \pm 0.01 \mathrm{ab} \\
\text { (19) }\end{array}$ \\
\hline $\mathrm{T}_{4}$ & $\begin{array}{c}4.75 \pm 0.03 \mathrm{e} \\
(21.91)\end{array}$ & $\begin{array}{c}181.0 \pm 0.21 \mathrm{f} \\
(5.55)\end{array}$ & $\begin{array}{c}6.10 \pm 0.11 \mathrm{~g} \\
(52.32)\end{array}$ & $\begin{array}{c}11.83 \pm 0.03 \mathrm{c} \\
(38.47)\end{array}$ & $\begin{array}{l}54 \pm 0.02 \mathrm{bc} \\
\quad(9.99)\end{array}$ \\
\hline $\mathrm{T}_{5}$ & $\begin{array}{c}4.94 \pm 0.02 \mathrm{de} \\
(26.34)\end{array}$ & $\begin{array}{l}190.5 \pm 0.35 \mathrm{e} \\
\quad(11.21)\end{array}$ & $\begin{array}{c}7.13 \pm 0.05 \mathrm{e} \\
(77.81)\end{array}$ & $\begin{array}{c}12.90 \pm 0.06 \mathrm{~b} \\
(51.15)\end{array}$ & $\begin{array}{l}55 \pm 0.01 \mathrm{ab} \\
(17.64)\end{array}$ \\
\hline $\mathrm{T}_{6}$ & $\begin{array}{c}5.50 \pm 0.15 \mathrm{~b} \\
(41.52)\end{array}$ & $\begin{array}{c}220.8 \pm 0.53 \mathrm{~b} \\
(28.90)\end{array}$ & $\begin{array}{c}8.20 \pm 0.02 b \\
(103.97)\end{array}$ & $\begin{array}{c}14.50 \pm 0.82 \mathrm{~b} \\
(62.43)\end{array}$ & $\begin{array}{c}56 \pm 0.04 \mathrm{a} \\
(26.20)\end{array}$ \\
\hline $\mathrm{T}_{7}$ & $\begin{array}{l}5.41 \pm 0.04 \mathrm{~b} \\
(38.28)\end{array}$ & $\begin{array}{c}215.0 \pm 1.78 \mathrm{c} \\
(25.90)\end{array}$ & $\begin{array}{c}8.00 \pm 0.04 \mathrm{c} \\
\quad(99.83)\end{array}$ & $\begin{array}{c}14.10 \pm 0.11 \mathrm{ab} \\
(66.07)\end{array}$ & $\begin{array}{c}56 \pm 0.02 \mathrm{ab} \\
(20.35)\end{array}$ \\
\hline $\mathrm{T}_{8}$ & $\begin{array}{c}5.86 \pm 0.05 \mathrm{a} \\
(49.87)\end{array}$ & $\begin{array}{c}234.4 \pm 2.83 \mathrm{a} \\
(36.66)\end{array}$ & $\begin{array}{c}8.43 \pm 0.02 \mathrm{a} \\
(109.44)\end{array}$ & $\begin{array}{c}14.60 \pm 0.03 \mathrm{a} \\
(71.51)\end{array}$ & $\begin{array}{l}57 \pm 0.01 \mathrm{ab} \\
(22.12)\end{array}$ \\
\hline $\operatorname{LSD}(\mathrm{p} \leq 0.05)$ & 0.17 & 3.08 & 0.15 & 0.72 & 1.90 \\
\hline
\end{tabular}

Table values (means of three replicates \pm S.E.) sharing a letter in common within a column do not differ significantly $(p<0.05)$. Values within parenthesis are percentage increase over control. $\mathrm{T}_{1}$ : Unfertilized control; $\mathrm{T}_{2}: \mathrm{NPK}$ at 250-150-125 $\mathrm{kg} \mathrm{ha}^{-1} ; \mathrm{T}_{3}: \mathrm{SM}$ at $15 \mathrm{tha}^{-1} ; \mathrm{T}_{4}: \mathrm{FYM}$ at $16 \mathrm{t} \mathrm{ha}^{-1} ; \mathrm{T}_{5}: \mathrm{PM}$ at $13 \mathrm{tha}^{-1} ; \mathrm{T}_{6}: \mathrm{NPK}$ at 150-85-50+8 $\mathrm{t}$ $\mathrm{ha}^{-1} \mathrm{SM} ; \mathrm{T}_{7}$ : NPK at 150-85-50+8.5 $\mathrm{tha}^{-1} \mathrm{FYM}_{\mathrm{g}}$ : NPK at 150-85-50 $+7 \mathrm{tha}^{-1} \mathrm{PM}$. SM : sheep manure ; FYM : farm yard manure ; PM : poultry manure. 


\section{Results}

Growth and yield attributes of maize were substantially affected by organic and inorganic sources of nutrients (Table 3). Integrated use of chemical fertilizer with poultry manure (PM) (NPK150-85-50 + 7.0 $\mathrm{t} \mathrm{ha}^{-1}$ ) resulted in maximum leaf area index (LAI), 1000-grain weight, grain yield, and biological yield. However, values for harvest index were highest in T6. Unfertilized controlled plots showed the lowest values for growth and yield attributes of maize. Hence, combined application of organic and inorganic nutrient sources improved maize performance than sole application of organic or inorganic fertilizer, nonetheless, PM remained more effective regarding maize growth and yield than FYM and SM. Results showed that soil $\mathrm{pH}$, soil $\mathrm{P}$, total organic $\mathrm{C}$ and total $\mathrm{N}$ were significantly affected by the application of organic and inorganic fertilizers.

Application of manures (organic or inorganic) alone or in combination reduced the soil $\mathrm{pH}$. Soil $\mathrm{pH}$ value of 7.5 was recorded in control (a little alkaline) whilst; minimum $\mathrm{pH}$ value (7.0) was recorded in $\mathrm{T}_{4}$ followed by $\mathrm{T}_{3}, \mathrm{~T}_{5}$ and $\mathrm{T}_{7}$ where organic manures were applied both alone or in combination (Figure 1a).
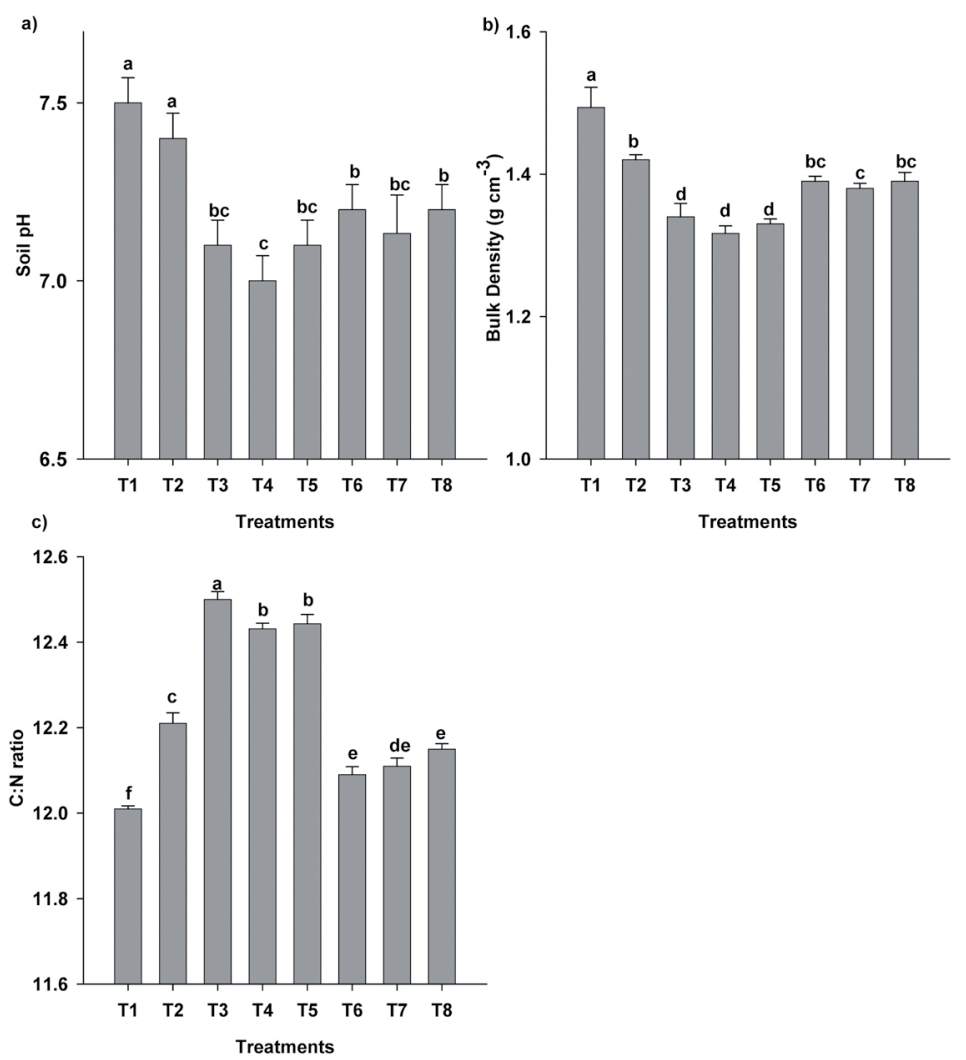

Figure 1. Residual Impact of organic and inorganic manures on (a) soil $\mathrm{pH}$, (b) Bulk density, and (c) on C:N ratio after crop harvest. Vertical bars sharing a letter in common are not significantly different at $p<0.05$. Treatment description is same as in table 3 . 


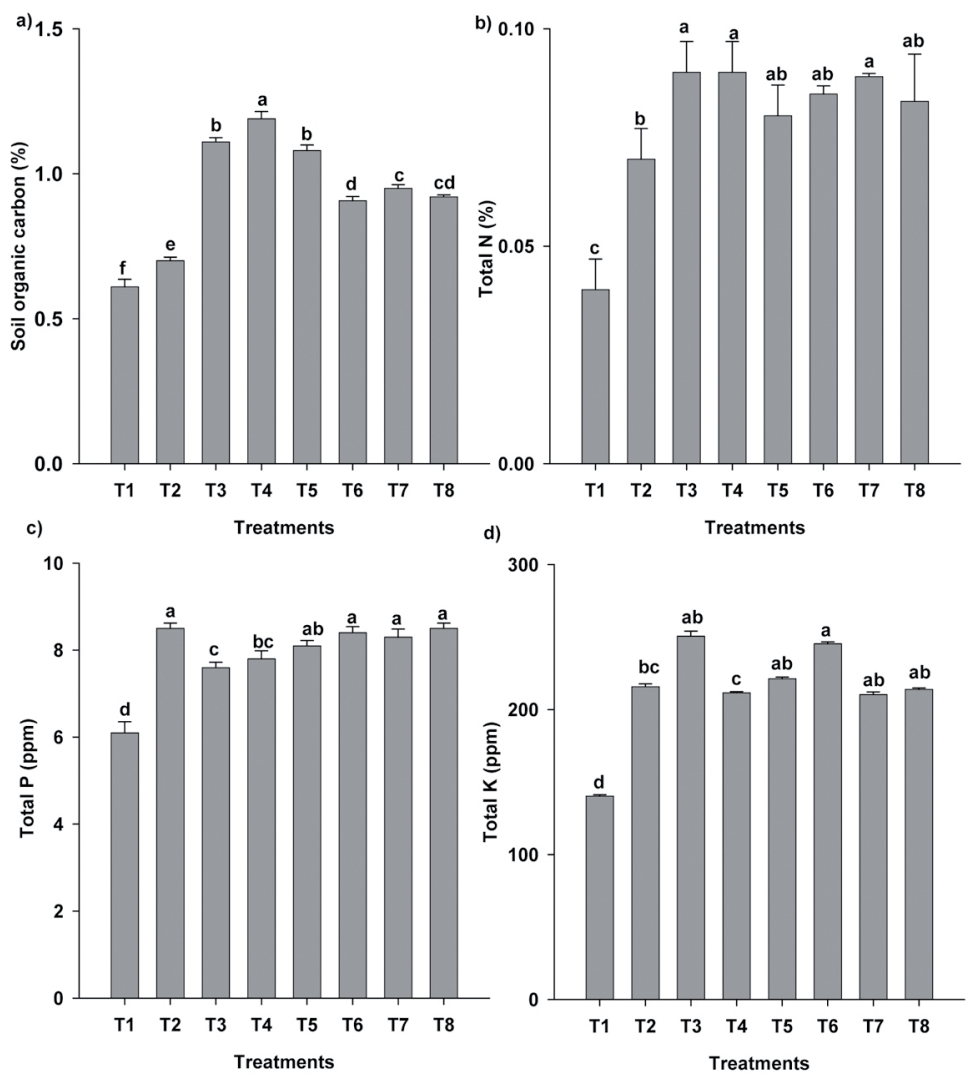

Figure 2. Residual Impact of organic and inorganic manures on (a) Soil organic carbon (\%), b) Total N (\%), (c) Total P (ppm), (d) Total K (ppm) after crop harvest. Vertical bars sharing a letter in common are not significantly different at $p<0.05$. Treatment description is same as in table 3 .

Hence, addition of organic manures irrespective to its nature, reduced soil $\mathrm{pH}$. Significant differences among the treatments were observed in soil bulk density as compared to the control. All plots treated with organic manures alone showed substantial reduction in soil bulk density followed by the plots where inorganic and organic fertilizers were applied in combination. Maximum bulk density was recorded in control treatments, however minimum was recorded in $\mathrm{T}_{4}$ which is at par with $\mathrm{T}_{2}$ and $\mathrm{T}_{5}$ (Figure 1b). C: $\mathrm{N}$ ratio of the soil treated with organic and inorganic manures affected significantly $(p \leq 0.05)$ (Figure 1c). In comparison to sole application of organic manure, combined application of both organic and inorganic manures showed lower values for $\mathrm{C}$ : $\mathrm{N}$ ratio. Among organic manures, $\mathrm{C}: \mathrm{N}$ ratio trend was: $\mathrm{SM}>\mathrm{FYM}>\mathrm{PM}$. The lower values of $\mathrm{C} / \mathrm{N}$ ratio for $\mathrm{PM}$ represent its higher $\mathrm{N}$ contents than FYM and SM.

A significant difference among the treatments for soil organic carbon and total nitrogen concentrations with application of organic and inorganic fertilizers were recorded. Application of organic fertilizer alone or in combination with inorganic fertilizer has increased the overall soil organic carbon and total $\mathrm{N}$ concentration 
(Figure $2 \mathrm{a} \& \mathrm{~b}$ ). Treatments with application of organic manures only $\left(\mathrm{T}_{4}, \mathrm{~T}_{3}\right.$ and $\left.\mathrm{T}_{5}\right)$ enhanced soil organic carbon than combined with inorganic fertilizer. Moreover, other treatments also improved soil organic carbon but remained least effective. Furthermore, maximum $\mathrm{N}$ concentration of $0.09 \%$ was recorded in $\mathrm{T}_{3}$ where sheep manure was applied but did not differ statistically from all other treatments except $\mathrm{T}_{2}$ and $\mathrm{T}_{1}$. Application of chemical fertilizers along with organic amendments improved $\mathrm{P}$ and $\mathrm{K}$ status of soil effectively. $\mathrm{T}_{2}$ proved better regarding soil $\mathrm{P}$ contents while $\mathrm{T}_{6}$ and $\mathrm{T}_{3}$ enhanced soil $\mathrm{K}$ contents substantially than control (unfertilized). Hence, SM proved more effective when applied in combination with chemical fertilizers than FYM and PM but it is dose dependent.
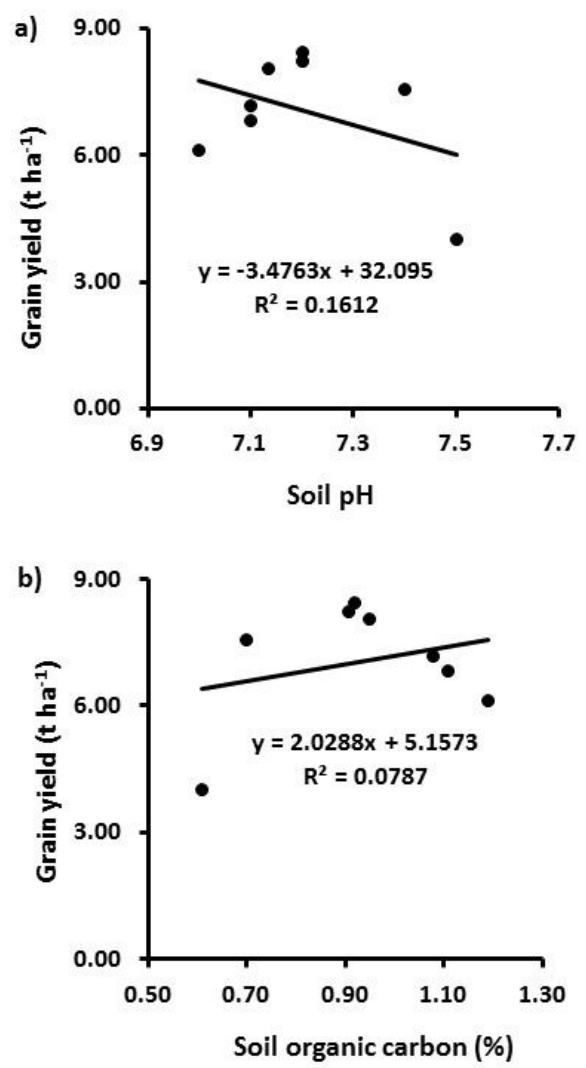

However, all three manures improved soil nutrient status than control that confirmed the increase in nutrient use efficiency of fertilizers when applied with organic manures (Figure $2 \mathrm{c} \& \mathrm{~d}$ ).

Maize grain yield was significantly correlated with soil characteristics affected by the addition of organic and inorganic manures in the soil. A significant positive correlation was found among grain yield and soil total N, P and K contents $\left(\mathrm{R}^{2}=0.53,0.91,0.55\right)$, respectively whilst the correlation among grain yield, soil organic carbon (SOC) and C: $\mathrm{N}$ ratio was also remained positive but non-significant. Moreover, a negative and non-significant correlation was found among maize grain yield, soil $\mathrm{pH}$ and soil bulk density (Figure 3 a-g).
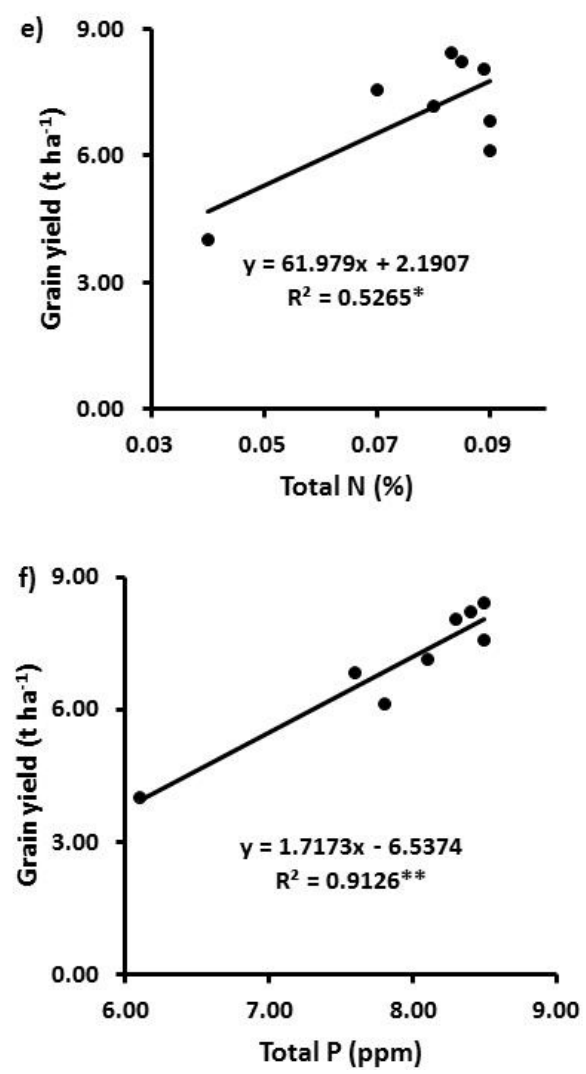

Figure 3. Correlation among maize grain yield and soil characteristics affected by organic and inorganic nutrient sources. *significant at $p \leq 0.05 ; * *$ significant at $p \leq 0.01$. 


\section{Discussion}

Undoubtedly, intensive cultivation with extreme use of chemical fertilizers increased crop productivity but on the other hand, it also disturbed the agro-ecosystems and polluted soil and water quality to a great extent. So, better management practices in which judicious use of fertilizers with some organic manures can be adopted to enhance crop productivity without/minimum damaging the nature. Here, we studied the individual and integrative effects of organic and inorganic manures on maize productivity and soil properties and found that combined application of both organic and inorganic sources of nutrients improved growth and yield and related attributes of maize (Table 1). Combination of organic manures might have improved the nitrogen use efficiency, micro and macro nutrient recovery and help in $\mathrm{P}$ solubilization and its uptake by the plants and enhanced $\mathrm{K}$ availability that in turn resulted in better growth and yield of maize. Increased organic matter due to application of organic manures improved crop performance and soil characteristics (Li et al., 2010). Therefore, combined application of organic and inorganic fertilizers is considered a good option to enhance nutrient recovery, plant growth and ultimate yield otherwise higher $\mathrm{N}$ and $\mathrm{P}$ application rates are required to attain better yield in maize (Mubeen et al., 2013). Further, these results are also in concurrence with Negassa et al. (2001) who found that corn yield was increased by $35 \%$ when combined (inorganic and organic) nutrients were applied. Shisanya et al. (2009) also reported similar results with improved growth and yield related attributes in cotton and maize, respectively. Combined application of organic and inorganic nutrient sources improved synergism and synchronization between nutrient release and plant recovery thus resulted in better crop growth and yield (Huang et al., 2010). Further, nitrogen use efficiency was higher in plants receiving poultry manure than other organic nutrient sources like pig manure, sheep manure, cattle slurry, ammonium sulphate (Rees and Castle, 2002). Conversely, (Javier and Tabien, 2003) did not found any statistical difference in rice yield in all plots either applied with organic, inorganic or combination of both manures.

Moreover, organic manures application along with inorganic fertilizers also induced alterations in physicochemical properties of soil (Figure 1 a-c \& Figure 2 a-d). Addition of organic manures, regardless to its nature, abridged soil $\mathrm{pH}$. Similar findings were also reported by Yaduvanshi (2003) that a reduction of soil $\mathrm{pH}$ occurs when green manure or farmyard manure was used in alkaline soils. Low pH value for FYM is very valuable for calcareous soils (Karami et al., 2012). Further, reduced bulk density might be due to increased soil biopores and soil aeration, higher soil organic carbon content, and better soil aggregation by the application of bulky organic manures that ultimately improved soil porosity and water holding capacity as well (Gangwar et al., 2006). Organic manure (from different sources) application enhanced soil porosity, soil moisture contents and water holding capacity while reduced soil compaction and bulk density (Papini et al., 2011). Moreover, Bandyopadhyay et al. (2010) also reported a negative correlation of soil bulk density of top $15 \mathrm{~cm}$ soil layer with the organic carbon contents present in it.

The lower C:N ratios in soils treated with combined organic and inorganic manures might be attributed to higher nitrogen availability due to addition of chemical fertilizer along with organic manures and its retention in the soil, which is consistent with lower rates of $\mathrm{N}$ losses than $\mathrm{C}$ losses during organic manure degradation (Chen et al., 2010). Organic amendments significantly enhanced SOC thus had a considerable effect on soil microbes and nutrient availability and uptake, thus may alter the $\mathrm{C}: \mathrm{N}$ ratio. However, the addition of external organic matter with high $\mathrm{C}$ : $\mathrm{N}$ 
ratio may also induce accelerated mineralization of the extant organic matter thereby releasing the nitrogen trapped in the extant organic matter- a phenomenon known as priming effect (Fontaine et al. 2004; Shahzad et al. 2015). Our results showed that SM has higher C: N ratio and lower SOC than FYM and PM. These findings are corroborated with the previous results in literature (Eghball et al., 2004; Huang et al., 2007; Agbede et al., 2008). Surface soil organic carbon buildup probably due to the addition of plant residues, root exudates, plant and root biomass in the surface layer that decreased with increased soil depth regardless of the manures applied (Brar et al., 2013).

Regarding nutrient status of the soil, all three organic manures with inorganic fertilizers improved plant growth and yield with a significant improvement in NPK contents of the soil that affirmed enhanced nutrient use efficiency in the presence of organic manures. Organic amendments with reduced dose of chemical fertilizers might have resulted in elicited microbial activity and nutrient availability more than application of chemical fertilizer alone and/or unfertilized control. Application of organic amendments improved soil N, P and K concentrations when applied with inorganic fertilizers (Hao et al., 2008). Organic manures have more beneficial effects on soil quality than inorganic fertilizers thereby improving nutrient release and their availability to the plants (Birkhofer et al., 2008).

The positive correlations between soil NPK status and the grain yield indicates that the soil nutrient status may affects grain yield and its components directly. These results are in confirmatory with Lima et al. (2009) who stated that incorporation of organic manures improves soil physico-chemical properties that may have a direct or indirect effect on plant growth and yield attributes.

\section{Conclusion}

In crux, application of organic manures has significant influence on maize productivity and soil physico-chemical properties. Manure efficacy regarding morphological indices of maize was: found as PM $>$ SM $>$ FYM when applied with chemical fertilizers. Further, C: N ratio, soil organic carbon and total NPK increased while soil $\mathrm{pH}$ and soil bulk density were decreased with the integrative application of organic manures and chemical fertilizer. Hence, organic manures can be applied with chemical fertilizers in organic carbon depleted arable soils to improve soil properties and crop productivity.

\section{References}

Agbede, T.M., Ojeniyi, S.O., Adeyemo, A.J. 2008. Effect of poultry manure on soil physical and chemical properties, growth and grain yield of sorghum in Southwest, Nigeria. AmericanEurasian J. Sus. Agri. 2, 72-77.

Anatoliy, G.K., Thelen, K.D. 2007. Effect of winter wheat crop residue on no-till corn growth and development. Agron. J. 99, 549-555.

Arau Jo, A.S.F., Monteiro, R.TR. 2006. Microbial biomass and activity in a Brazilian soil plus untreated and composted textile sludge. Chemosphere. 64, 1043-1046.

Ashraf, U., Salim, M.N., Sher, A., Sabir, S.R., Khan, A., Pan, G., Tang, X. 2016a. Maize growth, yield formation and water-nitrogen usage in response to varied irrigation and nitrogen supply under semiarid climate. Turk. J. Field Crops. 21(1), 87-95.

Ashraf, U., Abbas, R.N., Hussain, S., Mo, Z.W., Anjum, S.A., Khan, I., Tang, X.R. 2016b. Consequences of varied planting geometry and early post emergence herbicides for crop-weed interventions in rice under semi-arid climate. Planta Daninha 34 (4) 737-746. 
Bandyopadhyay, K.K., Misra, A.K., Ghosh, P.K., Hati, K.M. 2010. Effect of integrated use of farmyard manure and chemical fertilizers on soil physical properties and productivity of soybean. Soil Till. Res. 110, 115-125.

Brar, B.S., Singh, K., Dheri, G.S., Kumar, B. 2013. Carbon sequestration and soil carbon pools in a rice-wheat cropping system: Effect of longterm use of inorganic fertilizers and organic manure. Soil Till. Res. 128, 30-36.

Birkhofer, K., Bezemer, T.M., Bloem, J., Bonkowski, M., Christensen, S., Dubois, D., Ekelund, F., Fließach, A., Gunst, L., Hedlund, K., Ma“der, P., Mikola, J., Robin, C., Seta"la, H., Tatin-Froux, F., Van Der Putten, W.H., Scheu, S. 2008. Long-term organic farming fosters below and aboveground biota: implications for soil quality, biological control and productivity. Soil Biol. Biochem. 40, 2297-2308.

Chapman, H.D., Pratt, P.F. 1961. Methods of analysis for soils, plant and water. University California, Division Agriculture Science, Barkley, 68 p.

Chen, Y., Zhang, X.D., He, H.B., Xie, H.T., Yan, Y., Zhu, P., Ren, J., Wang, L.C. 2010. Carbon and nitrogen pools in different aggregates of a Chinese Mollisol as influenced by long-term fertilization. J. Soil Sediment 10, 1018-1026.

Dwyer, L.M., Stewart, D.W. 1986. Leaf area development in field-grown maize. Agron. J. 78, 334-343.

Eneji, A.E., Honna, T., Yamamoto, S., Saito, T., Masuda, T. 2002. Nitrogen transformation in four Japanese soils following manure + urea amendment. Commun. Soil Sci. Plan. 33, 53-66.

FAO. 2012. FAOSTAT, Production. 12, 2014.

Fontaine, S., Bardoux, G., Benest, D., Verdier, B., Mariotti, A., Abbadie, L. 2004 Mechanisms of the priming effect in a savannah soil amended with cellulose. Soil Science Society of America Journal, 68, 125-131.
Gangwar, K.S., Singh, K.K., Sharma, S.K., Tomar, O.K. 2006. Alternative tillage and crop residue management in wheat after rice in sandy loam soils of IndoGengetic plains. Soil Till. Res. 88, 242-252.

Hao, X., Liu, S., Wu, J., Hu, R., Tong, C, Su, Y. 2008. Effect of long-term application of inorganic fertilizer and organic amendments on soil organic matter and microbial biomass in three subtropical paddy soils. Nutr. Cycl. Agroecosys. 81, 17-24.

Hepperly, Y.P., Lotter, D., Ulsh, C.Z., Siedel, R., Reider, C. 2009. Compost, manure and synthetic fertilizer influences crop yields, soil properties, nitrate leaching and crop nutrient content. Compost Sci. Util. 17, 117-126.

Huang, B., Sun, W.Z., Hao, Y.Z., Hu, J., Yang, R., Zou, Z., Ding, F., Su, J. 2007. Temporal and spatial variability of soil organic matter and total nitrogen in an agricultural ecosystem as affected by farming practices. Geoderma 139, 336-345.

Huang, S., Weijian, Z.W., Yu, X., Huang, Q. 2010. Effects of long-term fertilization on corn productivity and its sustainability in an Ultisol of southern China. Agri. Ecosyst. Environ. 138, 44-50.

Javier, E.F., Tabien, R.E. 2003. Nitrogen dynamics in soils amended with different organic fertilizers. Philipp. J. Crop Sci. 28(3), 49-60.

Karami, A., Homaeea, M., Afzalinia, S., Ruhipour, H., Basirat, S. 2012. Organic resource management: Impacts on soil aggregate stability and other soil physico-chemical properties. Agri. Ecosyst. Environ. $148,22-28$.

Kihanda, F.M., Warren, G.P., Micheni, A.N. 2006. Effect of manure application on crop yield and soil chemical properties in a long-term field trial of semi-arid Kenya. Nutr. Cycl. Agroecosys. 76, 341-354.

Lima, D.L.D., Santos, S.M., Scherer, H.W., Schneider, R.J., Duarte, A.C., Santos, E.B.H., Esteves, V.I. 2009. Effects of organic and inorganic 
amendments on soil organic matter properties. Geoderma . 150, 38-45.

Merino, C., Godoy, R., Matus F. 2016. Soil enzymes and biological activity at different levels of organic matter stability. J. Soil Sci. Plant Nutr. 16(1), $14-30$.

Mubeen, K., Iqbal, A., Hussain, M., Zahoor, F., Siddiqui, M.H., Mohsin, A.U., Bakht, H.F.S.G., Hanif, M. 2013. Impact of Nitrogen and Phosphorus on the Growth, Yield and Quality of Maize (Zea mays L.) Fodder in Pakistan. Philipp. J. Crop Sci. 38(2), 43-46.

Negassa, W., Negisho, K., Frison, D.K., Ransom, J., Yadessa, A. 2001. Determination of optimum FYM and NP fertilizers for maize on farmers' field. Soil. Sci. Soc. Am. J. 56, 476-484.

Papini, R., Valboa, G., Favilli, F., L'abate, G. 2011. Influence of land use on organic carbon pool and chemical properties of Vertic Cambisols in central and southern Italy. Agri. Ecosyst. Environ. $140,68-79$.

Rees, R., Castle, K. 2002. Nitrogen recovery in soils amended with organic manures combined with inorganic fertilizers. Agronomie. 22, 739-746.

Saha, S., Mina, B.L., Gopinath, K.A., Kundu, S., Gupta, H.S. 2008. Organic amendments affect biochemical properties of a subtemperate soil of the Indian Himalayas. Nutr. Cycl. Agroecosys. $80,233-242$.
Schoebitz, M., Vidal G. 2016. Microbial consortium and pig slurry to improve chemical properties of degraded soil and nutrient plant uptake. J. Soil Sci. Plant Nutr. 16 (1), 226-236.

Shahzad, T., Chenu, C., Genet, P., Barot, S., Perveen, N., Mougin, C. \& Fontaine, S. (2015) Contribution of exudates, arbuscular mycorrhizal fungi and litter depositions to the rhizosphere priming effect induced by grassland species. Soil Biology and Biochemistry, 80, 146-155.

Spargo, J.T. 2004. Availability and surface runoff of phosphorus from compost amended mid-Atlantic soils: master's thesis, Virginia Tech, Blacksburg, VA.

Shisanya, C., Mucheru, M., Mugendi, D.N., Kungu, J.B. 2009. Effect of organic and inorganic nutrient sources on soil mineral nitrogen and maize yields in central highlands of Kenya. Soil Till. Res. 103, 239-246.

Toor, G.S., Bahl, G.S. 1997. Effect of solitary and integrated use of poultry manure and fertilizer phosphorous on the dynamics of $\mathrm{P}$ availability in different soils. Bioresource Technol. 62, 25-28.

Yaduvanshi, N.P.S. 2003. Substitution of inorganic fertilizers by organic manures and the effect on soil fertility in a rice-wheat rotation on reclaimed sodic soil in India. J. Agri. Sci. 140, 161-168. 